\title{
Allergic diseases of the skin and drug allergies - 2019. Higher doses for heavy hives
}

\author{
Kiran Godse \\ From 2nd WAO International Scientific Conference (WISC 2012) \\ Hyderabad, India. 6-9 December 2012
}

\section{Background}

Nonsedating antihistamines are recommended as first line treatment for patients with urticaria.

\section{Methods}

In our study, 30 patients with chronic urticaria for at least six weeks were enrolled after an informed written consent. Out of 30 patients 16 were females and 14 were males, in the age group of 16 yrs to 55 yrs (average age 33 yrs).

Patients with urticaria activity score (UAS) of 3 or more than 3 ,were started on tablet levocetirizine in a dose of $10 \mathrm{mg}$ at bedtime at the onset of the treatment.

Out of 30 patients only 5 patients were symptomatic at the end of one week and were started on $20 \mathrm{mg}$ of levocetirizine. Three out of 5 patients were asymptomatic after starting higher dose of $20 \mathrm{mg}$ at the end of $2^{\text {nd }}$ week with reduction in UAS. Twenty eight out of 30 patients showed good response and decrease in the UAS within two weeks, with higher dose of levocetirizine. However 2 patients showed no response to treatment even with 20 mgs of levocetirizine.

Average UAS at 0 week was 4.767 , it came down to 1.8 at the end of one week. At the end of two weeks UAS was 1.4. At the end of 4 weeks average UAS came down to 0.4, showing a marked downward trend with high doses of levocetirizine given at the very onset of the disease. Therefore patients with higher UAS at the time of presentation should be started on a higher dose of levocetirizine at the onset of the treatment for better symptomatic relief and suppression of the disease within one week.

\section{Results}

According to the findings in our study use of a higher dose of non sedating antihistamine in patients with UAS

Dermatology, DR.D.Y.Patil Medical College and Hospital, India of 3 or more than 3 at the very start of the therapy brings about a better control and rapid supression of the symptoms, suggesting the need for "higher doses for heavy hives".

\section{Conclusions}

we suggest higher doses for heavy hives.

Published: 23 April 2013

doi:10.1186/1939-4551-6-S1-P106

Cite this article as: Godse: Allergic diseases of the skin and drug

allergies - 2019. Higher doses for heavy hives. World Allergy Organization Journal 2013 6(Suppl 1):P106.
Submit your next manuscript to BioMed Central and take full advantage of:

- Convenient online submission

- Thorough peer review

- No space constraints or color figure charges

- Immediate publication on acceptance

- Inclusion in PubMed, CAS, Scopus and Google Scholar

- Research which is freely available for redistribution
() Bïomed Central

\section{() Biomed Central}

